\title{
International Comparison of Egg Production Cost and Marketing Margin-A Study of 15 Selected Countries
}

\author{
Arunasiri Iddamalgoda, Michio Sugiyama Katsuyuki Oguri \\ Katsumi Arahata*, Satoshi $\mathrm{KaI}^{* *}$ and Jin Chun Ryu*** \\ The United Graduate School of Agricultural science, Gifu University \\ 1-1 Yanagido, Gifu 501-1193, Japan \\ * Faculty of Agriculture, Gifu University, Gifu, Japan \\ ** Department of Agricultural Economics, Faculty of agriculture \\ Kyushu University, Hakozaki, Fukuoka, Japan \\ *** Dept. of Agriculture Economics, Faculty of Agriculture, Kyung Pook \\ National University, Teagu 702-701, Rep. of Korea
}

The present study examined the production cost factors and marketing margin involved in producing eggs in the surveyed countries. In this study the egg production cost is defined as the total of the direct costs (feed and chick) and indirect costs (labor, machinery \& implement, building, power and medicine). Marketing margin is considered as the difference between egg retail price and producer price. The cost of production for eggs varies widely around the world and the feed cost is the single most important factor among them followed by labor and bird depreciation cost. The objectives of this study are; to analyze the different cost factors affecting the production of a kilogram of eggs ; to compare the marketing margin from producer to retailer. In order to fulfill the objectives, 15 selected countries around the world were surveyed during 1996. Data were collected based on different cost factors as well as producer and retailer prices for the respective countries.

It is evident from the study that grain producing countries like USA, Brazil, China and India had a considerably low cost in producing eggs. Other developing countries, even though not considered as grain producers, had a lower cost due to cheap labor and low chick cost. Countries such as Netherlands and UK where technical standards are similar to United States, have high production cost due to the high competitive cost of feed and labor. The surveyed countries were divided into high cost, medium cost and low cost according to the cost of production levels. With the favorable trade in the future, world egg production will expand and may concentrate in areas where the low cost feed grains are available. China will continue to be the largest egg producer in the world and its export potential is high especially since the opening of new markets with the annexation of Hong Kong. India and Brazil too have tremendous future potential with the large consumer market and increasing household income. Egg trade will continue to improve within the respective regions and therefore the share of major exporters like Netherlands will have a reduction of its export to Asia as well as within the EU countries.

(Jpn. Poult. Sci., 35 : 234-244, 1998)

Key words : production cost, direct cost, feed cost, housing-labor cost, marketing margin 


\section{Introduction}

World egg production has increased by an average of around 1 million tonnes a year during the period 1985-1993. The most dramatic increase in terms of quantity of egg produced in the past 10 years is Asia and this industry is one of the fastest growth region at the moment. Not only are population numbers rising, in most countries of the region, but real disposable incomes are also growing, enabling more people to buy animal protein for the first time, or in bigger quantities if they are already doing so. Therefore it is important to concentrate on cost factors affecting egg production in order to keep a reasonable profit for producer and keep an affordable price to the consumer.

According to the white paper on Japanese Agriculture (1996), the percentage of price differences of food items varies among the major cities in the world. For instance, the egg price in New York was $72 \%$ of the Tokyo price. However in London, Paris and Copenhagen it was $166 \%, 156 \%$ and $215 \%$ respectively. For beef, in New York it was $77 \%$ of the Tokyo price and in other cities it was $78 \%, 72 \%$ and $122 \%$ respectively. Prices are affected by production cost as well as marketing cost and the available resources vary among countries. This study is an attempt to understand the production cost and price levels in the egg sector among the selected countries with different levels of economic development.

Production cost varies between feed producing countries and feed importing countries. Even though the feed cost is relatively high in many developing countries, the cheap labor cost is still able to keep the egg price reasonable in the market. To better understand the present and future prospects of egg production, it is important to know about cost factors involving egg production. Comparative cost studies are also required and are quite important because of the increase of trade under WTO. Under these circumstances the purpose of this study is to analyze the various cost factors and prices and compare the production factors among the surveyed countries.

The methods of cost analysis differs among surveyed countries and parameters concerned also differ according to its economical importance and availability. In some countries, cost calculation is done by a government organization and others by government or private agencies. Since feed cost is the most important factor many studies are mainly emphasize only this factor for calculating the cost. However this study attempts to outline the importance of other factors especially labor cost and other fixed costs. Few international comparisons have been done and they are mainly focused on either feed cost or chick cost. Therefore a comprehensive cost study must be done giving importance to all levels of cost factors during egg production. However, the costs are affected by the production and its marketing as well as the whole structure of the economy. However, it is important to calculate, compare and consider the egg cost and price level, especially after the WTO agreements.

\section{Method of Study}

A Cost survey has conducted between April to October in 1996. A standard 
survey questionnaire was mailed to 15 selected countries and the data were collected on egg production cost and prices at different marketing levels. In this study total cost is the result of main factors such as feed, bird depreciation, labor, machinery, heat, water, power, veterinary and medicine. All the national currencies were converted to dollar based on the average for 1995. Japan had high fluctuation during this year. The national currency level is also an important factor for comparison of the cost of eggs, so, each countries currency is converted by each countries enumerator. Therefore, it is more accurate than our single estimation. Countries were divided into three groups according to the cost level.

The lower cost group countries were China, India, Iran, Sri Lanka, and Bangladesh. High cost groups included countries such as Japan, Rep. of Korea, Taiwan, Canada and United kingdom and middle cost nations are U.S.A, Netherlands, Saudi Arabia, Nepal and Brazil. The lowest cost group between $\$ 0.464-\$ 0.690$, Medium is $\$ 0.707-\$ 0.887$ and high group between $\$ 0.907-\$ 1.655$. Export countries are Netherlands, U.S.A and China, import countries are Japan, U.K and China and major import nations among the studied countries are Canada, U.K and Japan. With particular reference to production cost, it must be noted that actual cost may vary within the country depending on factors such as scale of operation and supply of inputs.

\section{Result and Discussion}

\section{Production Cost Factors}

An analysis of the cost of producing eggs in the studied countries reveals wide disparity. Among these countries there are a few differences in the breakdown of cost factors. Countries like USA had 4 published efforts to determine cost. USDA published a very general type cost analysis. It is noted that the breakdown of costs is not the same even within a country. To maintain uniformity, this survey included main cost factors like feed stuff, bird depreciation cost, labor, machinery and implement, heat, water and power, medication and others.

Table 1 shows the breakdown of egg production cost per kilogram and this is calculated for large size eggs which have the highest demand among various egg sizes. Total cost to produce a kg of eggs varies from the highest 165.5 cents to the lowest 46.4 cents. Each cost factor varies among theses countries.

\section{Feed cost}

It is lower in feed producing countries and therefore the lowest in producing one kilogram of eggs are China, USA, Brazil, India and Canada. Feed cost is the main factor affecting egg production but in the non feed producing countries the total production cost is lower due to cheap labor such as in India and China. Figure 1 reveals the percentage of feed cost in total cost. It is clearly indicated that over $70 \%$ of total egg production cost incurred by India (80.8\%), Bangladesh (87.1\%), Iran (86.1\%), China (85.6\%), Nepal (77.5\%), Saudi Arabia (77\%) and Sri Lanka (76.1\%). Therefore the future development in the livestock and poultry sector will depend on the availability of grains which equally compete with increasing human population.

In the developed countries, the feed industry is the most important consumer of 
Table 1. Egg Production Cost per Kilogram

(Unit : US \$ Cents $/ \mathrm{kg}$ )

\begin{tabular}{l|r|r|r|r|r|r|r|r|r|r}
\hline \hline & Japan & $\begin{array}{c}\text { South } \\
\text { Korea }\end{array}$ & Taiwan & China & $\begin{array}{c}\text { Sri } \\
\text { Lanka }\end{array}$ & India & $\begin{array}{c}\text { Bangla- } \\
\text { desh }\end{array}$ & Nepal & Iran & $\begin{array}{c}\text { Saudi } \\
\text { Arabia }\end{array}$ \\
\hline Feeding Stuff & 92.3 & 71.5 & 57.4 & 39.7 & 52.1 & 44.6 & 60.1 & 59.1 & 59.1 & 57.2 \\
Bird Depriciation & 34.0 & 27.2 & 13.1 & 2.3 & 9.0 & 4.5 & 3.4 & 6.8 & 6.8 & 3.7 \\
Labour & 25.3 & 18.0 & 11.7 & 2.0 & 2.6 & 0.6 & 2.0 & 4.8 & 4.8 & 8.4 \\
Machienery \& Implement & 8.5 & 3.4 & 3.8 & 0.3 & 2.6 & 0.3 & 0.9 & 2.3 & 2.3 & 1.0 \\
Heat, Water, Power & 3.3 & 0.9 & 1.4 & 0.4 & 1.5 & 0.3 & 0.7 & 2.7 & 2.7 & 1.6 \\
Veterinary \& Medicine & 1.0 & 0.9 & 2.5 & 0.5 & 0.7 & 3.3 & 1.3 & 1.8 & 1.8 & 1.5 \\
Others & 1.1 & 1.3 & 0.7 & 1.2 & - & 0.1 & 0.7 & 0.1 & 0.1 & 1.0 \\
\hline \multicolumn{1}{c}{ Total } & 165.5 & 123.2 & 90.6 & 46.4 & 68.5 & 53.7 & 69.1 & 77.6 & 77.6 & 74.4 \\
\hline
\end{tabular}

(Unit : US \$ Cents/kg)

\begin{tabular}{l|r|r|r|r|r|r}
\hline \hline & Japan & U.S.A & $\begin{array}{r}\text { Canada } \\
\text { Nether- } \\
\text { land }\end{array}$ & U.K & Brazil \\
\hline Feeding Stuff & 92.3 & 41.8 & 47.4 & 52.0 & 63.2 & 42.7 \\
Bird Depriciation & 34.0 & 11.0 & 22.0 & 20.5 & 21.8 & 15.2 \\
Labour & 25.3 & 6.0 & 21.9 & 7.0 & 8.9 & 4.1 \\
Machienery \& Implement & 8.5 & - & 9.0 & 3.8 & 1.7 & 0.7 \\
Heat, Water, Power & 3.3 & - & 3.2 & 2.7 & 6.5 & 0.3 \\
Veterinary \& Medicine & 1.0 & - & 4.3 & n.a & 1.8 & 0.4 \\
Others & 1.1 & 13.7 & 8.9 & 2.7 & 1.1 & 7.3 \\
\hline & 165.5 & 72.5 & 116.7 & 88.7 & 105.0 & 70.7 \\
\hline
\end{tabular}

Source : Cost of egg production Survey, 1996.

grains. Compound feed production amounted to around 550 million tonnes in 1993, of which one third was poultry feed. This proportion is growing, primarily at the expense of cattle feeds.

\section{Bird Depreciation Cost}

This cost is used as a "ready to lay" pullet cost divided by the number of dozen eggs laid. For example, in California according to Don Bell (1996), ready to lay pullet cost was $\$ 2.50$ and 34 dozen eggs laid in a two cycle flock. Therefore depreciation cost is around 7.4 cents/dozen. Bird depreciation cost is higher in Japan and Korea due to high ready to lay pullet cost. It is quite rare to sell pullets at the age of 16 weeks and the growing cost from day old to 16 weeks which includes many production cost factors.

\section{Labor cost}

Labor cost is a significant factor in many developed countries in spite of large scale production with less labor utilization with the adoption of windowless automated poultry houses. The exception is USA where the labor cost for producing a kilogram of eggs was a fourth of the cost in Japan. However in all surveyed developing Asian nations the labor was a cheaper input in production. Among them India recorded the lowest labor cost followed by Bangladesh, Iran and China. Even the scale of production is not so large in these nations and backyard poultry rearing still contribute a 


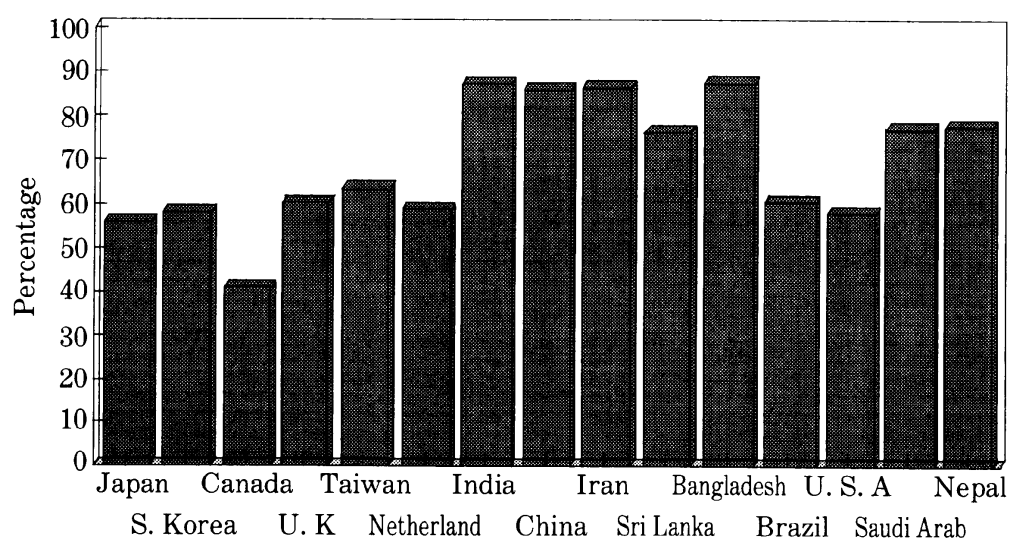

Fig. 1 Percentage of Feed Cost from Total Cost

significant portion of egg production.

Many laying farms in the developing countries practiced mixed farming where the farmer derived income from other crops and applied all the manure generated from livestock activities including poultry. Many of these farmers have reasonable profit because the labor is provided by the farmer and his family. Egg cost is considered to be lower in developing countries due to predominantly existing backyard and mixed farming type production. There is less manure disposal cost in these countries because of the application of poultry litter to crop production.

The difference in overall production cost between the lowest cost and the highest cost countries is $\$ 1.191$ per kilogram of eggs. The difference in feed cost to produce one kilogram of eggs between the lowest cost country (China 39.7 cents) and the highest cost Japan (92.3 cents) is 52.6 cents (US\$). The bird depreciation cost is highest for Japan (34.0 cents) and the lowest for India (4.5 cents). This difference comes to about 29.5 cents. Even though the feed cost is the most important cost factor, the other cost factors have a significant variation among surveyed countries in producing a kilogram of eggs. In high labor cost countries, the mechanization of poultry farming is practiced in order to reduce the labor cost, however, the housing cost will be high. While in the low cost countries, it takes more labor hours during production because of inconvenient poultry houses. Therefore, it is important to compare the labor and machinery cost collectively as "housing-labor costs" in international studies.

Figure 2 shows the contribution of different cost factors among low, medium and high cost countries. However in Japan building tax is charged even for poultry houses and surprisingly it is the same as normal dwelling house tax. Therefore in addition to other high cost factors in Japan building cost and tax is also attributed to high production cost. Non egg income in order to reduce egg associated cost and other sources of income like fowl manure are so minimal anyway, it would make little difference.

Therefore the surveyed countries can be classified into 3 major groups based on the total production cost.

1. Low Cost Countries (LCC) : $\$ 0.464-\$ 0.690$ : China, India, Sri Lanka, Iranand 
Bangladesh.

2. Medium Cost Countries (MCC) : $\$ 0.707-\$ 0.887$ : Brazil, USA, Nepal, Netherlands and Saudi Arabia.

3. High Cost Countries (HCC) : \$0.907-\$1.655 : Japan, Republic of Korea, Taiwan, UK and Canada.

\section{Ratio of Different Cost Factors}

For this comparison, different cost factors are calculated as a percentage from total cost. According to Table 2 the feed cost is over $80 \%$ in the countries such as Bangladesh $(87.1 \%)$, Iran (86.1\%), China (85.6\%), India (80.8\%) and Sri Lanka, Nepal and Saudi Arabia it is accounted to over $75 \%$. A kilogram of feed is quite similar in these

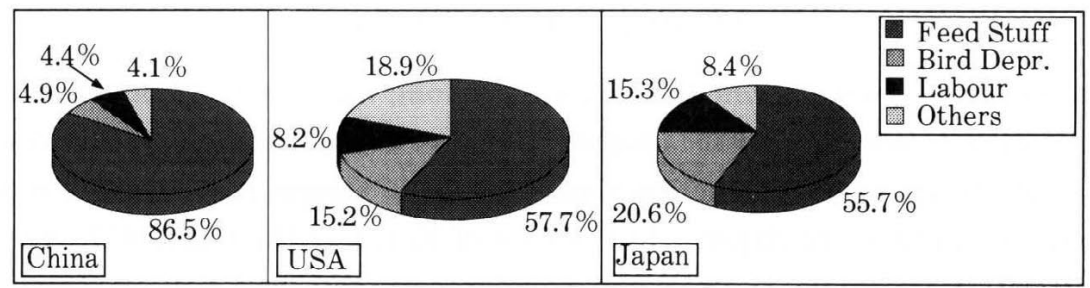

Fig. 2 Breakdown of Production Cost in low. Medium and High Cost coutries

Table 2. Percentage of different cost factors per kg of egg production

\begin{tabular}{l|r|r|r|r|r|r|r|r|r|r}
\multicolumn{1}{c|}{} & Japan & S. Korea & Taiwan & China & $\begin{array}{c}\text { Sri } \\
\text { Lanka }\end{array}$ & India & $\begin{array}{c}\text { Bangla- } \\
\text { desh }\end{array}$ & Nepal & Iran & $\begin{array}{c}\text { Saudi } \\
\text { Arabia }\end{array}$ \\
\hline Feeding Stuff & 55.8 & 58.0 & 63.3 & 85.6 & 76.0 & 80.8 & 87.1 & 76.2 & 86.1 & 77.1 \\
Bird Depriciation & 20.6 & 22.1 & 14.5 & 4.9 & 13.1 & 8.1 & 4.9 & 8.8 & 4.4 & 5.0 \\
Labor & 15.3 & 14.6 & 12.9 & 4.4 & 3.7 & 1.2 & 2.8 & 6.2 & 2.3 & 11.3 \\
Machienery \& Implement & 5.1 & 2.8 & 4.2 & 0.6 & 3.8 & 3.3 & 1.3 & 2.9 & 4.1 & 1.3 \\
Heat, Water, \& Power & 2.0 & 0.7 & 1.5 & 0.8 & 2.2 & 0.5 & 0.9 & 3.4 & 2.0 & 2.1 \\
Veterinary \& Medicine & 0.6 & 0.7 & 2.8 & 1.1 & 1.1 & 5.9 & 1.9 & 2.3 & 0.8 & 2.0 \\
Others & 0.7 & 1.1 & 0.8 & 2.6 & 0.0 & 0.2 & 0.9 & 0.2 & 0.2 & 1.3 \\
\hline \multicolumn{1}{c}{ Total } & 100.0 & 100.0 & 100.0 & 100.0 & 100.0 & 100.0 & 100.0 & 100.0 & 100.0 & 100.0 \\
\hline
\end{tabular}

Unit : \%

\begin{tabular}{l|r|r|r|r|r|r}
\hline \hline & Japan & USA & $\begin{array}{r}\text { Canada } \\
\text { Nether- } \\
\text { land }\end{array}$ & U.K & Brazil \\
\hline Feeding Stuff & 55.8 & 57.7 & 40.7 & 58.6 & 60.2 & 60.4 \\
Bird Depriciation & 20.6 & 15.2 & 18.9 & 23.1 & 20.8 & 21.5 \\
Labor & 15.3 & 8.2 & 18.7 & 7.9 & 8.5 & 5.7 \\
Machienery \& Implement & 5.1 & 0.0 & 7.7 & 4.3 & 1.6 & 1.0 \\
Heat, Water, \& Power & 2.0 & 0.0 & 2.7 & 3.0 & 6.2 & 0.5 \\
Veterinary \& Medicine & 0.6 & 0.0 & 3.7 & 0.0 & 1.7 & 0.6 \\
Others & 0.6 & 18.9 & 7.6 & 3.0 & 1.0 & 10.3 \\
\hline \multicolumn{1}{c}{ Total } & 100.0 & 100.0 & 100.0 & 100.0 & 100.0 & 100.0 \\
\hline
\end{tabular}

Source : Cost of egg production Survey, 1996. 
surveyed countries but the percentage of feed cost in total cost is quite low due to other comparatively high cost factors.

Day old chick also contributes to high ready to lay pullet cost. Table 3 presents the feed price, day old chick price and ready to lay pullet cost (16 weeks) in the surveyed countries. Variation in day old chick cost to a larger extent reflects differences in feed cost, and to a smaller extent other factors including layer performance. This indicates the wide difference in day old chick and ready to lay pullet cost between USA and Japan. The highest day old chick cost is in Japan which is around 132.24 cents and the cheapest in China which is around 32.45 cents (Hunton, Weibe, 1997). The ready to lay pullet cost is high in Japan (667.58 cents) and the lowest is China (168.27).

\section{Cost Factors Compared to Japan}

Japan is the highest cost incurred country among the surveyed countries. Hence it is interesting to see how far it is higher when we compare against other countries. Table 4 reveals where cost reduction should be made among the surveyed countries. USA feed cost is $45.3 \%$ of Japan. In the case of Korea $77.4 \%$, China $43 \%$, Sri Lanka $56.4 \%$, Brazil $46.3 \%$, India $48.3 \%$ when compared to the feed cost in Japan. Bird Depreciation cost in Korea is $79.8 \%$ of Japan and for UK $64.1 \%$, Netherlands $60.2 \%$, Brazil $44.7 \%$, China $6.6 \%$ and in India $13.2 \%$.

It is noted that to produce a kilogram of eggs, the labor cost in India is $2.5 \%$ of Japan and for USA 23.5\%, Brazil 16.15\%, Rep. of Korea $71.1 \%$, Taiwan $46.2 \%$ and China $8.0 \%$. Since the labor cost as well as feed cost are quite low there is huge potential in future egg industries in the countries such as USA, Brazil, China \& India. There are few countries where heat, water, power and medication expenses are considerably higher than the corresponding figure for Japan.

To compare future export potential, United States is the most appropriate country to be considered. USA is a large exporter of feed ingredients and its domestic feed

Table 3. Price of Feed, Chicks and Pullets per Country (July, 1996)

(Unit : US dollar cents)

\begin{tabular}{l|c|c|c|c}
\hline \hline \multicolumn{1}{c|}{ Country } & $\begin{array}{c}\text { Feed Price } \\
(\mathrm{kg})\end{array}$ & $\begin{array}{c}\text { D/O Chick } \\
\text { Price (A) }\end{array}$ & $\begin{array}{c}\text { Pullet cost }(\mathrm{F}) \\
\text { 16-wk. (B) }\end{array}$ & $\begin{array}{c}\text { C=B-A } \\
(\mathrm{D} / \mathrm{O})\end{array}$ \\
\hline Japan & 33.83 & 132.24 & 667.58 & 535.34 \\
Canada & 22.73 & 76.97 & 359.21 & 282.24 \\
U.K & 26.76 & 70.34 & 359.33 & 288.99 \\
Taiwan & 29.50 & 79.14 & 356.44 & 277.30 \\
Netherland & 23.39 & 70.18 & 336.26 & 266.08 \\
India & 24.29 & 38.86 & 228.57 & 189.71 \\
China & 26.44 & 32.45 & 168.27 & 135.82 \\
Sri Lanka & 24.69 & 28.70 & 235.38 & 206.68 \\
Bangladesh & 26.25 & 58.47 & 369.93 & 311.46 \\
Brazil & 18.50 & 58.00 & 250.89 & 192.89 \\
USA & 18.50 & 46.00 & 225.00 & 179.00 \\
\hline
\end{tabular}

Source : World Poultry, January 1997. 
Table 4. Percentage of Cost factors compared to Japan

Unit.\%

\begin{tabular}{l|r|r|r|r|r|r|r|r|r|r}
\hline \hline & Japan & S. Korea & Taiwan & China & $\begin{array}{c}\text { Sri } \\
\text { Lanka }\end{array}$ & India & $\begin{array}{c}\text { Bangla- } \\
\text { desh }\end{array}$ & Nepal & Iran & $\begin{array}{c}\text { Saudi } \\
\text { Arabia }\end{array}$ \\
\hline Feeding Stuff & 100.0 & 77.4 & 62.2 & 43.0 & 56.4 & 48.3 & 65.1 & 64.0 & 56.2 & 62.0 \\
Bird Depriciation & 100.0 & 79.8 & 38.5 & 6.6 & 26.4 & 13.2 & 10.0 & 20.0 & 7.9 & 10.8 \\
Labor & 100.0 & 71.1 & 46.2 & 8.0 & 10.1 & 2.5 & 7.8 & 19.0 & 5.4 & 33.2 \\
Machienery \& Implement & 100.0 & 40.4 & 45.1 & 3.5 & 31.0 & 3.3 & 10.7 & 26.7 & 29.4 & 11.2 \\
Heat, Water, \& Power & 100.0 & 27.5 & 42.1 & 11.5 & 46.6 & 8.2 & 20.0 & 81.0 & 37.5 & 47.7 \\
Veterinary \& Medicine & 100.0 & 89.6 & 247.1 & 51.3 & 71.6 & 326.0 & 127.3 & 172.2 & 48.7 & 144.3 \\
Others & 100.0 & 119.3 & 65.6 & 109.0 & 0.0 & 8.2 & 59.2 & 11.4 & 12.4 & 86.6 \\
\hline \multicolumn{1}{c}{ Total } & 100.0 & 74.4 & 54.8 & 28.0 & 41.4 & 32.4 & 41.7 & 46.8 & 36.4 & 44.9 \\
\hline
\end{tabular}

Cost of Production compared to Japan

\begin{tabular}{l|r|r|r|r|r|r}
\multicolumn{1}{|c|}{} & Japan & USA & Canada & $\begin{array}{c}\text { Nether- } \\
\text { land }\end{array}$ & U.K & Brazil \\
\hline \hline Feeding Stuff & 100.0 & 45.3 & 51.4 & 56.3 & 68.5 & 46.3 \\
Bird Depriciation & 100.0 & 32.3 & 64.7 & 60.2 & 64.1 & 44.7 \\
Labor & 100.0 & 23.5 & 86.6 & 27.7 & 35.2 & 16.1 \\
Machienery \& Implement & 100.0 & 0.0 & 106.0 & 44.6 & 20 & 7.9 \\
Heat, Water, \& Power & 100.0 & 0.0 & 96.6 & 82.5 & 198.6 & 10.3 \\
Veterinary \& Medicine & 100.0 & 0.0 & 417.2 & \multicolumn{1}{c}{0} & 175.3 & 39.5 \\
Others & 100.0 & 1240.9 & 805.8 & 244.6 & 99.6 & 661.6 \\
\hline \multicolumn{1}{c}{ Total } & 100.0 & 43.8 & 70.5 & 53.6 & 63.4 & 42.7 \\
\hline
\end{tabular}

Source : Cost of egg production survey, Gifu University, 1996.

market is a reasonably good indicator of international feed prices. Countries such as Brazil, China, India, Sri Lanka, Bangladesh and Iran, where the overall cost production is cheaper, the cost advantage is gained from low cost factors like labor and other related costs. To understand the general agriculture input prices, the following example is taken from the White Paper on Japanese Agriculture. According to its finding, supplier price of tractors in USA is $84 \%$ of the Japanese price. Wages are $56 \%$, Chemicals are $65 \%$ and Fertilizers are $45 \%$ of the Japanese price. Therefore the future of agriculture as well as the livestock sector including the egg sector in USA is far more competitive than in Japan.

The Netherlands, the largest exporter in the world, has very efficient performance in egg production but has high production costs because of poor raw material cost and high non feed cost. In almost all the surveyed countries the genetic potential of available chicks are basically the same because of the universal distribution of almost all the popular breeds at the moment.

\section{Marketing Margin}

Producer price and retail price per $\mathrm{kg}$ of egg is tabulated in Table 5 and the marketing margin is calculated on the data of 1990 and 1994. Some data were collected 
Table 5. Marketing Margin of Egg from Prtoducer to Ratailer

Unit : US\$

\begin{tabular}{|c|c|c|c|c|c|c|}
\hline & \multicolumn{3}{|c|}{1990} & \multicolumn{3}{|c|}{1994} \\
\hline & $\begin{array}{l}\text { Producer } \\
\text { Price (P) }\end{array}$ & $\begin{array}{c}\text { Retail } \\
\text { Price (R) }\end{array}$ & $\begin{array}{c}\text { Margin } \\
\mathrm{M}=\mathrm{R}-\mathrm{P} ; \mathrm{M} / \mathrm{P} \%\end{array}$ & $\begin{array}{l}\text { Producer } \\
\text { Price }(\mathrm{P})\end{array}$ & $\begin{array}{c}\text { Retail } \\
\text { Price (R) }\end{array}$ & $\begin{array}{c}\text { Margin } \\
\mathrm{M}=\mathrm{R}-\mathrm{P} ; \mathrm{M} / \mathrm{P} \%\end{array}$ \\
\hline Japan & 1.63 & 2.30 & $0.67(41.1 \%)$ & 1.60 & 2.70 & $1.10(68.8 \%)$ \\
\hline S. Korea & 0.80 & 0.97 & $0.17(21.3 \%)$ & 0.74 & 1.08 & $0.34(45.9 \%)$ \\
\hline Canada & 1.38 & 2.07 & $0.69(50.0 \%)$ & 1.30 & 1.58 & $0.28(21.5 \%)$ \\
\hline UK & 0.33 & 0.83 & $0.50(152.0 \%)$ & 0.40 & 1.10 & $0.70(175 \%)$ \\
\hline Taiwan & 0.87 & 1.21 & $0.34(39.1 \%)$ & 1.03 & 1.44 & $0.41(39.8 \%)$ \\
\hline Netherland & 1.03 & 2.13 & $1.1 \quad(107.0 \%)$ & 0.84 & 2.23 & $1.39(166.0 \%)$ \\
\hline India & 0.56 & 0.70 & $0.14(25.0 \%)$ & 0.54 & 0.62 & $0.08(15.0 \%)$ \\
\hline Iran & 0.67 & 0.89 & $0.22(32.8 \%)$ & 0.66 & 0.77 & $0.11(17.0 \%)$ \\
\hline Sri Lanka & 0.67 & 0.80 & $0.13(19.3 \%)$ & 0.65 & 0.88 & $0.23(35.2 \%)$ \\
\hline Bangladesh & 0.80 & 1.07 & $0.27(34.0 \%)$ & 0.83 & 1.17 & $0.34(41.0 \%)$ \\
\hline USA & 0.88 & 2.63 & $1.75(199.0 \%)$ & 0.72 & 2.47 & $1.75(243.0 \%)$ \\
\hline Nepal & 1.01 & 1.20 & $0.19(19.0 \%)$ & 1.02 & 1.14 & $0.12(12.0 \%)$ \\
\hline
\end{tabular}

Data : Survey on Egg production Cost, 1996.

* Percentage of marketing margin is mentioned in the brackerts.

in dollars and the others converted to dollars on the basis of average exchange rates for 1990 and 1994. Collected data were mainly for large size eggs which have the highest preference from the consumers. Egg production costs are discussed in the earlier chapters and were calculated for 1996, so there are differences in the producer prices of 1994 and sometimes a slight difference occurred during the two year period.

In developed countries the marketing margin is larger between the producer price and the retail price when compared to developing countries. This indicates that several marketing activities are taking place from farm to retailer. Sometimes there are long marketing channels from the producer area to the consumer area or it maybe the result of packing cost which is still low in developing countries. Transportation cost is also high when the retail market is far away from the producing areas. In contrast, developing countries availability of packed eggs is still quite low and the market is very close to the producer area as a large number of egg producers are following small scale production systems. For example, in USA the margin is $199 \%$ of the producer price however in India it is $25 \%$ of the producer price.

Developed or large scale producing countries marketing margin from farm gate to retailer price has expanded but within the developing countries the margin has slightly contracted or almost at the same level as in 1990. This may be due to the large amount of eggs coming from small scale farmers or backyard poultry rearing in developing nations and capital cost has not changed much compared to developed countries. Purchasing power of eggs differ in countries irrespective of food prices and living standard. For example, a Japanese can buy about 40 eggs for his one hour labor but a Indian can buy about 8-10 eggs and a Sri Lankan can buy only about 4 eggs. 


\section{Summary}

It is very important to estimate the cost of production with reference to all cost factors and have it published on a regular basis to the understand present situation of egg industry and its business opportunities. China, the world number one egg producer with the largest consumer market, will look for export markets although it is not self sufficient in feed stuff due to competition among other livestock sectors and increasing population and rapidly improving disposable income. India is clearly one of the countries with huge potential in the egg industry as the chick and feed prices are comparable to US and it will have a prosperous future. Brazil, a low cost producing country, has the potential to become a major player in world trade.

European countries feed prices are high due to Common Agriculture Policy (CAP) but egg prices are low because the EU market is more than self sufficient. Japan is one of the highest cost markets, with a developed economy and has a high degree of potential in its agricultural industry. However, its egg \& broiler industries are now threatened by the increasing imports to the country.

Feed price consist of 70 to $80 \%$ of production cost and it is the most variable cost among all. This will have a direct affect on the domestic food situation as well as impact on the international feed Industry (market). Second most important factor is labor cost but it will have less effect in the short term as wages do not have a fluctuating affect like feed prices. Changes in currency exchange rates are also an important factor affecting the international studies. Nevertheless, the comparison of egg prices and marketing margin are important in the future with the increasing of international trade. International comparision of egg quality, consumption levels and methods of calculation are important problems for comparative studies in the fututre.

\section{Acknowledgment}

Our sincere appreciation to the following experts who are duely responded to this survey.

Professor G. Devegowda, University of Agricultural Sciences, Bangalore, India.

Dr. Donald BeLl, Poultry Specialist, University of California, USA.

Mr. Firooz. N. Pourazar, Vice Ministry of Economic Affairs, Iran.

Dr. Md. Nazrul Islam, Director, Dept. of Livestock Services, Bangladesh.

Dr. Tulsi. P. Shrestha, National Livestock Officer (FAO), Nepal.

Mr. Robert Botsford, National Farm Products Council, Canada.

Dr. Arend MiJs, Secretary General, ANEVEI, Netherlands.

Mr. Mark Williams, Statistical Adviser, IEC, UK.

Dr. H.P. PremasiRI, Manager, Technical Services, Gold Coin Feed Company, Sri LanKa.

Dr. Mohammad H. AL-QunAiBet, Dept. of Agri. Economics, College of Agriculture, King Saud University, Saudi Arabia.

Dr. G.S. Singh, Deputy Commissioner (Meat and Meat Products), Ministry of Food Processing Industries, India.

Dr. C. Ming-CHIEN, Dept. of Agri. Economics, National Taiwan University, Taiwan. 
Wiebe Van der Sluis, Editor, Misset World Poultry, Misset International, Netherlands.

\title{
References
}

Cho Yonghoon, Yamashita, M., Katsuyuki, O., Sugiyama, M. (1996)"Feasibility Study of Actual Egg Production Costs". Research Bulletin, Faculty of Agriculture, Gifu University, Japan, 61 : 101-109.

Hunton, P., Wiebe van der Sluis (1997)"Comparing the World Egg Industries". World Poultry, 13 : $42-45$.

Henry, R., Rothwell, G., (1995) The World Poultry Industry: IFC Global agribusiness series, pp. $30-44$.

Sugiyama, M. (1993)"Poultry Industry in the World and Japan". Farming Japan, 27-1, 10-21.

SugiYama, M. (1996) Applicability of Egg Cost Information, A Study of Animal Husbandry: Chikusan no Kenkyu, 50-8: 843-844.

WATT Poultry Statistical Yearbook 1996 : WATT publishing Co., pp. 36-41.

White Paper on Japanese Agriculture (1996), Ministry of Agriculture, Forestry and Fisheries, Govt. of Japan, pp. 100-104.

\section{鶏卵生産費と流通マージンの国際比較}

\author{
一世界 15 力国の比較分析一
}

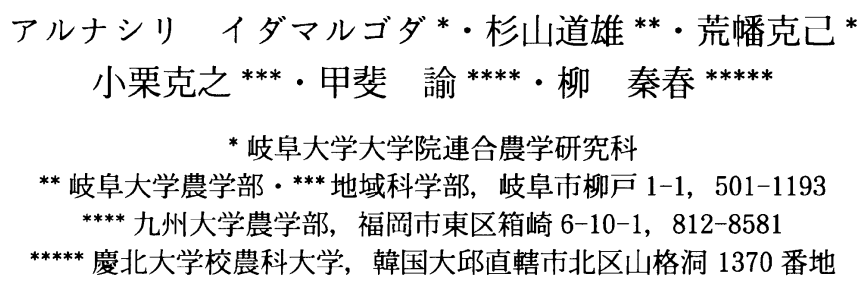

世界主要都市における鶏卵価格の内外価格差は，かな り大きいことが指摘されてきたが，その卵価水準に最む 影響する生産費と流通マージンの国際比較分析について 飼料費を除き，殆ど研究されていない。研究は国内でな されてあ国際比較はなされていないのは，生産費の概念 が統一されず，不明確であったことにもよっている。

本研究は鶏卵生産費の概念を直接費（飼料費十ひな 費）之間接費（労働，建物費，機械，道具費，農薬費等） として，1996 年世界 20 力国の政府，大学機関にメール メリッドで調査票を送付し，15 カ国につき回答を得て比 較分析を行ったあのである。調査国にはアメリカ，カナ ダ，イギリス，オラング，ブラジル，インド，中国，バ ングラデイシュ，ネパール，スリランカ，イラン，サウ ジアラビア, 日本, 韓国, 台湾の 15 力国である。これら の国は低生産費国, 中生産費国, 高生産費国に大別され るが，低生産費は高生産費国である日本の $1 / 3$ 近くで生 産している。低生産費国の主な要因は単に飼料費が安い ばかりではなく, 安い労働費の影響が大きい。中生産費
国は主としてアメリカなどで，近代的技術ばかりでな く, 飼料費が安いことに基づく。高生産費国は飼料の輸 入国であり，やや高くなるばかりでなく，貢金が高くな る。高労働費を節約するため施設化が進む場合，労働費 や施設費を個々に比較するのでなく，同じく労働節減機 能をもつものとして施設・労働費として比較されるべき である。

マーケティングマージンをみると，日本はその近代的 設備を導入しているものの, 労兵率は高く, 飼料費も高 い。

これらの結果から, 各国に生産費, 価格水準の比較に 当たっては飼料費, 雛費の直接費ばかりでなく間接費が 重要となる。とくに間接費のうちであ労働費，施設費を 合体した施設・労㗢費として比較すべきである。

（家禽会誌，35：234～244, 1998) キーワード : 鶏卵生産費, 直接費, 飼料費, 設備・労働 費, 流通マージン 